\title{
Edinsel Hepatoserebral Dejenerasyon: Olgu Sunumu
}

\author{
Acquired Hepatocerebral Degeneration: A Case Report
}

\author{
Eren GÖZKE ${ }^{1}$, Mustafa ESER ${ }^{1}$, Sıdıka Sinem TAŞDEMİR ${ }^{1}$, Pelin Doğan AK ${ }^{1}$
}

\section{Să̆llk Bilimleri Üniversitesi, Fatih Sultan Mehmet Ĕgitim ve Araştırma Hastanesi, Nöroloji Kliniği, İstanbul}

$\ddot{O Z Z T}$

Kronik karaciğer hastalıkları nörolojik belirti ve bulgularla ortaya çıkabilir. Seruloplazmin eksikliğine bağll olarak gelişen ve genetik kökenli olan Wilson hastalı̆̆ en bilinen örnektir. Başka kronik karaciğer patolojileri de klinik tablodan sorumlu olabilir. Kranial MR'da bazal ganglionlar düzeyinde özellikle mangan olmak üzere ăglr metal birikimleri görülür. Burada denge bozukluğu, dilde peltekleşme, ellerde titreme ve istemsiz hareketleri olan kriptojenik siroz tanil, edinsel (nonWilsonian) hepatolentiküler dejenerasyon olarak değerlendirilen 54 yaşındaki kadın hasta sunulmaktadır.

Anahtar kelimeler: kronik karaciğer hastalı̆̆l, edinsel hepatoserebral dejenerasyon, hareket bozukluğu

\section{ABSTRACT}

Chronic liver diseases can manifest itself with neurological sign and symptoms. Wilson disease is a rare genetic disorder related to ceruloplasmin deficiency and best-known example of chronic liver diseases related neurological findings. Also other chronic liver pathologies can be responsible for clinical picture. Cranial MRI shows heavy metal deposits, especially manganese, at the level of basal ganglions. Here we present a 54-year-old female patient diagnosed with acquired (non-Wilsonian) hepatolenticular degeneration related to cryptogenic cirrhosis who has balance disorder, dysarthria, tremor at hands and involuntary movements.

Keywords: chronic liver diseases, acquired hepatocerebral degeneration, movement disorder

\section{iletişim Bilgileri}

Sorumlu Yazar: Eren GÖZKE

Yazışma Adresi: Sağlık Bilimleri Ünv., Fatih Sultan Mehmet Eğitim ve Araştirma Hastanesi, E-5 Karayolu Üzeri, İ̧erenköy, Ataşehir, ìstanbul Tel: +90 (216) 5783000

E-Posta: egozke@hotmail.com

Makalenin Geliş Tarihi: 24.03.2017

Makalenin Kabul Tarihi: 06.04.2017

\section{GíRiș}

Geç başlangıçlı hareket bozuklukları ile başvuran hastalarda metabolik ve sistemik hastalıklar etyolojide yer alabilir. Kronik karaciğer hastalıkları ensefalopati ve hareket bozuklukları başta olmak üzere çeşitli nörolojik bulgularla karşımıza çıkabilir. Wilson hastalığ 1 hareket bozukluğuna neden olan kronik karaciğger hastalıkları arasında ilk sırada yer alır. Bununla birlikte başka karaciğer patolojileri de hepatoserebral dejenerasyon tablosuna neden olabilirler (1). Burada nörolojik bulguları olan kriptojenik sirozlu bir olgu sunulmaktadir.

\section{OLGU}

54 yaşında kadın hasta; denge bozukluğu, dilde peltekleşme, ellerde titreme ve istemsiz hareketler nedeni ile incelendi.

Bir yıldır denge bozukluğu, yürürken etrafa çarpma, dilde peltekleşme ve ellerde titremesi olan olgunun şikayetlerinde giderek artış olmuş. Düşme sonucu gelişen fraktür nedeni ile 2011 yilinda omurgasina operasyon uygulanmış. Travma nedeni ile hastanede yattığ 1 süreç içerisinde rutin kontrollerinde karaciğer yetmezliği ve üçüncü evre özofagus varisleri saptanarak gastroenteroloji bölümü tarafından kriptojenik karaciğer sirozu tanısı konmuş ve özofagus varisleri için propronalol tedavisi başlanmış. Nörolojik şikayetleri bu olaydan sonra giderek artan hastaya başka bir merkezde pirasetam ve anemi için demir preperatı başlanmış.

Özgeçmişinde düşme sonucu gelişen fraktür ile ilgili omurilik operasyonu dişında özellik olmayan hastanın soy geçmişinde de özellik saptanmadi.

Fizik muayenede arteriyel kan basinc1 $120 / 80 \mathrm{mmHg}$, nabiz dakikada 80 ve ritmik olarak bulundu. Ödem, ikter, siyanoz yoktu. Batın muayenesinde splenomegali saptandi. 


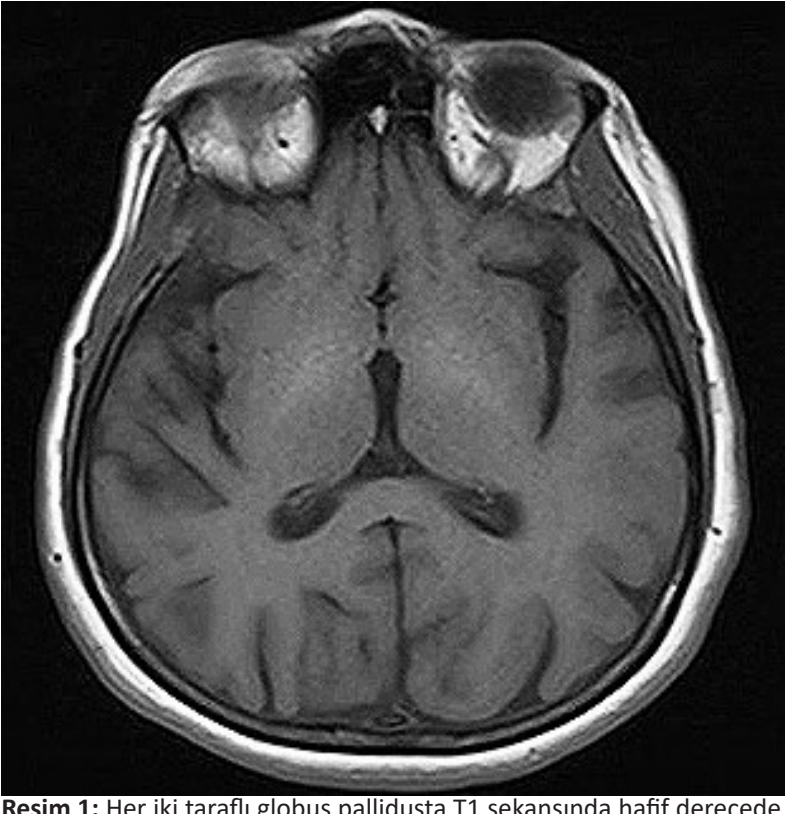

Resim 1: Her iki taraflı globus pallidusta T1 sekansında hafif derecede hiperintens görünüm.

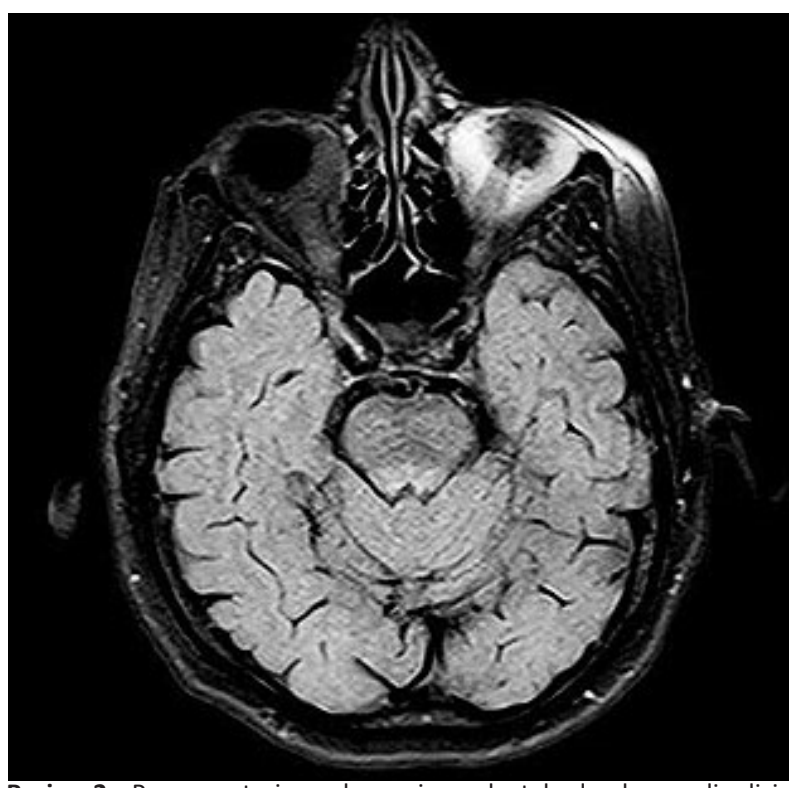

Resim 2: Pons posteriorunda periaquaductal alanda myelinolizis açısından şüpheli sinyal artışları.

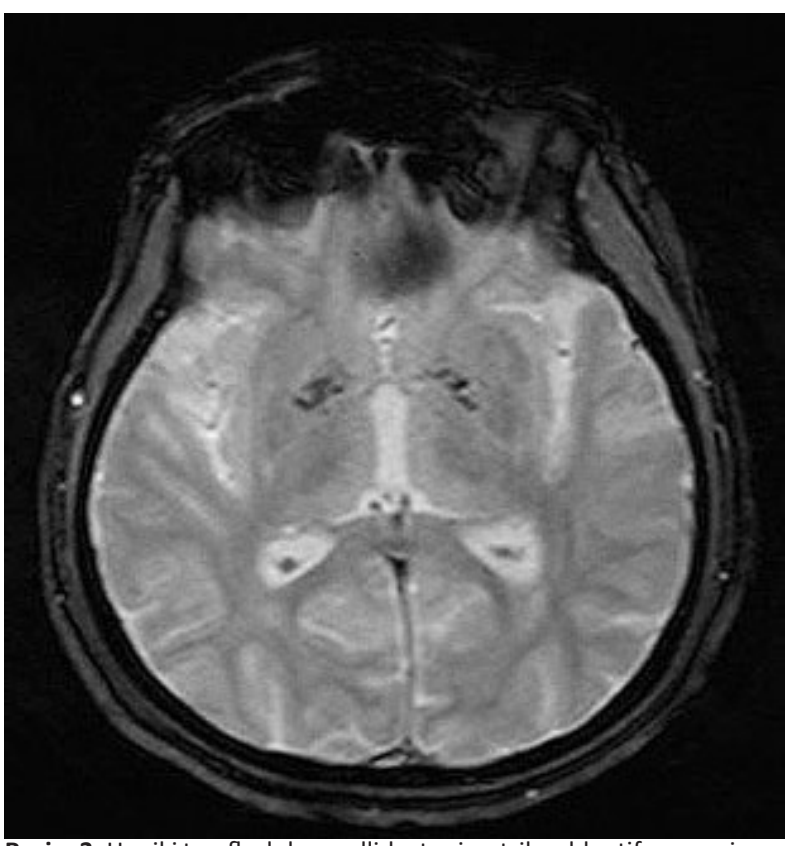

Resim 3: Her iki taraflı globus pallidusta simetrik sublentiform seviyeye uzanım gösteren T2 GRE sekansında milimetrik hipointens değişiklikler.
Nörolojik muayenede bilinç açık, kooperasyon ve orientasyon tamdi. Ancak hafif apati hali mevcuttu. Ense sertliği yoktu. Pupiller izokorik ve orta hatta idi. Ișik refleksi $+/+$ ve fundus normal sinırlarda bulundu. Ekstraoküler göz hareketleri her yöne serbestti. Fasiyal asimetri yoktu. Dil ve uvula orta hatta idi. Kas gücü tüm ekstremitede $5 / 5$ bulundu ve tonus normaldi. His kusuru yoktu. Derin tendon refleksleri: $+++/+++$, Taban derisi refleksi: fleksör/fleksör olarak alındı. Dizartrik konuşma mevcuttu. Yürüyüş ataksikti ve Romberg pozitif bulundu. Bilateral dismetri, disdiadokinezi, postural ve aksiyonel tremor mevcuttu. Muayene sirasinda istemli hareketle tetiklenen koreoatetoid hareketler, ağ $1 \mathrm{z}$ çevresinde belirgin diskinetik hareketler izlendi.

Rutin laboratuar bulgularında $\mathrm{Hb}: 10 \mathrm{~g} / \mathrm{dL}$, eritrosit: $3.13 \mathrm{M} / \mathrm{uL}$, lökosit: $2 \mathrm{~K} / \mathrm{uL}$, trombosit:49 K/uL, Anti-Hbs (+), Hbs Ag(-), AntiHCV (-), Anti HIV (-), AST ve ALT normal, GGT hafif yüksek olarak bulundu. INR: 1.46 idi. Vit B12 ve folat düzeyleri normaldi. 24 saatlik idrarda ve serumda bakır düzeyi ve serum seruloplazmin düzeyi normal bulundu. Serum ferritini de normaldi. Serum Mangan düzeyi $23,4 \mu \mathrm{g} / 1$ (üst sinır $11 \mu / 1$ ); Amonyak $209,2 \mu \mathrm{g} / \mathrm{dl}$ (üst sınır 87) idi. Lomber ponksiyonda BOS değerleri normal sınırlarda bulundu. EEG normal sınırlarda olarak yorumlandı.

Batın BT'de multipl evre 3 özofagus varisleri, kronik KC hastalığı ve splenomegali saptand1. Kranial MR'da her iki tarafli globus pallidusta T1 sekansinda hafif derecede hiperintens görünüm; pons posteriorunda periaquaductal alanda myelinolizis açısından şüpheli sinyal artışları; her iki taraflı globus pallidusta simetrik sublentiform seviyeye uzanım gösteren T2 GRE sekansında milimetrik hipointens değişiklikler izlendi (Resim 1, 2, 3).

Pansitopeni nedeniyle iç hastalıkları tarafından değerlendirilen hastada periferik yayma sonucu normaldi. Pansitopeni splenomegali ile ilişkilendirildi.

Hastanın nörolojik bulgularının kriptojenik siroza bağlı olarak beyin parankiminde mangan, amonyak ve demir birikimine bağlı olduğu düşünüldü.

\section{TARTIŞMA}

Edinsel (non-Wilsonian) hepatoserebral dejenerasyon progressif piramidal, ekstrapiramidal, serebellar bulgular ve mental bozukluklar ile karakterizedir. Kronik karaciğer hastalığında, özellikle portosistemik shunt 
varlığında, ensefalopati atakları olmaksızın ortaya çıkan kalıcı nörolojik defisitler ile giden nadir görülen bir tablodur. İlk kez 1914 yılında Woerkem tarafından bildirilmiștir (Wilson'dan iki y1l sonra). Daha sonra Victor, Adams ve Cole tarafindan ayrıntılı olarak tanımlanmıștır (1). Prevelans tam bilinmemektedir. Başlangıç genellikle 6.-7. dekadlardadır. Sinsi ya da subakut başlayabilir.

Genellikle progresif olmakla birlikte arada stabil seyredebilir. Sürvi haftalar-yıllar düzeyindedir. Ölüm nedeni karaciğer yetmezliğinin komplikasyonlarıdır (enfeksiyonlar, koagulopati, hepatorenal sendrom, hepatoselüler karsinom, hepatik koma). Kliniği Wilson hastalığına oldukça benzemekle beraber serum bakır ve seruloplazmin düzeyleri normal sinırlar içindedir ve Kayser-Fleisher halkas1 saptanmaz. Parkinsonizm, ataksi, distoni, kore ve orobukkolingual stereotipi, (fenomenolojik olarak tardif diskineziye benzeyen) görülebilir (2). Portosistemik şant varlığında portal dolaşımda bulunan nöroaktif maddeler hepatik metabolizma ve bilier eliminasyon ile yok edilemeyerek sistemik dolaşımla beyne geçer. Spesifik bir nörotoksin gösterilmemiştir. Amonyak düzeyi hepatik ensefalopatide önemlidir (3).

Aromatik amino asidler (triptofan, fenilalanin, tirozin) dopaminerjik yolları bozmaları nedeni ile klinik bulguların ortaya çıkışında adaydırlar. Son iki dekaddaki bulgular ağır metaller ve özellikle mangan üstünde yoğunlaşmaktadır. En belirgin nöropatolojik bulgu serebral ve serebellar korteks, bazal ganglionlar ve diensefalik nükleuslardaki protoplazmik astrositlerin (tip II Alzheimer hücreleri) hiperplazisidir (4).

T1-ağırlıklı MR görüntülerinde artmış sinyal intensitesi sık görülmez. Görüldüğü zaman lipid birikimi, hemorajilerde demir gibi paramanyetik maddeler ve melanin pigmentine bağlı olarak melanomalar düşünülmelidir.
Globus palliduslarda birikmeye daha yatkın olduğu deneysel hayvan çalışmalarında gösterilen manganez, T1-ağırlıklı serilerde hiperintens sinyallere neden olur (5-7).

Tedavide şelatör ajanlar (EDTA, trientin), dallanmış zincirli aminoasitler (lösin, izolösin, valin), laktuloz, antibiyotikler kullanilır. Mangandan fakir (tahıl, kuruyemiş, çay, meyve ve sebzeler) diyet önerilir. Mümkün olursa karaciğer transplantasyonu yapılabilir. Nörolojik semptomlarin tedavisinde mevcut bulgulara göre dopamin agonistleri, levodopa, ya da dopamin antagonistleri, tetrabenazin verilebilir $(3,8)$.

\section{KAYNAKLAR}

1. Ropper AH, Samuels MA. Chronic acquired (nonWilsonian) hepatocerebral degeneration. In: Adams, Victor's editor. Principles of Neurology. Ninth Edition. New York: McGraw Hill; 2009:1099-1100.

2. Ferrara J, Jankovic J. Acquired hepatocerebral degeneration. J Neurol 2009; 256:320-332.

3. Romeiro FG, Américo MF, Yamashiro FS, Caramori $C A$, Schelp AO, Santos AC et al. Acquired hepatocerebral degeneration and hepatic encephalopathy: correlations and variety of clinical presentations in overt and subclinical liver disease. Arq Neuropsiquiatr. 2011 Jun;69(3):496-501.

4. Burkhard PR, Delavelle J, Du Pasquier R, Spahr L. Chronic parkinsonism associated with cirrhosis: a distinct subset of acquired hepatocerebral degeneration. Arch Neurol 2003;60:521-528.

5. Lee J, Lacomis D, Comu S, et al. Acquired hepatocerebral degeneration: MR and pathologic findings. Am J Neuroradiol 1998; 19:485-487.

6. Klos KJ, Ahlskog JE, Josephs KA, Fealey RD, Cowl CT, Kumar N. Neurologic spectrum of chronic liver failure and basal ganglia $T 1$ hyperintensity on magnetic resonance imaging. Arch Neurology 2005;62:1385-1390.

7. Klos KJ, Ahlskog J E, Kumar N, Cambern S, Butz J, Burritt $M$ et al. Brain metal concentrations in chronic liver failure patients with pallidal T1 MRI hyperintensity. Neurology 2006; 67:1984-1989.

8. Wijdicks EF, Wiesner RH. Acquired (non-Wilsonian) hepatocerebral degeneration: complex management decisions. Liver Transpl 2003;9:993-994. 